\title{
PERAN E-WOM POSITIF DAN SIKAP WISATAWAN DALAM MENINGKATKAN NIAT BERKUNJUNG PADA GENERASI MILLENIAL (STUDI PADA GEOWISATA SELO BONANG KABUPATEN JEMBER)
}

\author{
Sri Lilik Puji Rahayu \\ Universitas Negeri Surabaya \\ srirahayu16080574029@mhs.unesa.ac.id
}

\begin{abstract}
Before conducting tourism activities, prospective tourists will consider several factors including e-WOM, and their attitude towards tourist destinations before carrying out activities that will give rise to the intention of visiting tourist destinations. This study aims to determine the effect of positive eWOM and intention to travel to Selo Bonang Geotourism by using mediating variables from tourist attitudes. This research uses quantitative data. The sampling technique used is non-probability sampling with the type of judgmental sampling. In this study, the sample used was 220 respondents using non-probability sampling techniques. Data is processed using path analysis techniques. The results of this study indicate that positive e-WOM has a positive and significant influence on tourist attitudes, tourist attitudes have a positive and significant effect on visit intention, and positive e-WOM has a positive and significant impact on visit intention, with mediation proven partially.
\end{abstract}

Keywords: attitude; e-WOM; visit intention.

\section{PENDAHULUAN}

Pariwisata merupakan salah satu sektor penunjang perekonomian Indonesia yang mengalami peningkatan setiap tahunnya, seiring meningkatnya pertumbuhan industri pariwisata menjadikan sektor ini sebagai salah satu penyumbang devisa terbesar di Indonesia dan ditetapkan sebagai salah satu sektor pembangunan nasional yang diharapkan mampu menjadi leading sector, core business dan sekaligus mampu menggerakkan pertumbuhan sektor industri lainnya. Dikutip dari (Kumparan travel, 2019) Menteri Pariwisata Arief Yahya menyatakan bahwa internet turut berperan dalam pengembangan pariwisata di Indonesia. Melalui survei yang dilakukan oleh APJII (2018) dan polling Indonesia, pengguna internet di Indonesia semakin mengalami peningkatan yakni menjadi 171,8 juta jiwa di tahun 2018.

Seiring meningkatnya laju pertumbuhan industri pariwisata dan pesatnya penggunaan internet menimbulkan sebuah fenomena yang terjadi pada sebagian besar masyarakat Indonesia khususnya generasi millenial di mana mereka memiliki sebuah pemikiran baru, yaitu menganggap kegiatan travelling sebagai kebutuhan untuk mendapatkan kesenangan sekaligus menunjukkan pilihan gaya hidup mereka (Travel.tempo.com, 2019). Sebelum seseorang memutuskan untuk melakukan travelling, akan muncul keinginan dan niat (intention) terlebih dahulu dalam benak calon wisatawan yang timbul karena ada sebuah ketertarikan terhadap sebuah destinasi wisata Cahyanti \& Anjaningrum (2018). Niat merupakan bagian dari perilaku konsumen tertentu (Schiffman \& Kanuk, 2008:222). Niat berkunjung merujuk pada probabilitas yang dirasakan oleh calon wisatawan dalam waktu tertentu sehingga calon wisatawan tersebut dapat membangun persepsi yang memengaruhi tingkah laku dan keputusan akhir dalam menentukan sebuah destinasi wisata yang akan dikunjungi (Whang, Yong, \& Ko, 2016).

Achmat (2015) menjelaskan bahwa sebagian ahli beranggapan dalam membentuk niat seseorang dapat dimulai dari sikap. Ajzen (2005) dalam teorinya yang berjudul Theory of Planned Behavior (TPB) mengungkapkan bahwa anteseden pertama dari tujuan berperilaku adalah sikap. Penilaian positif dari seorang individu akan membuat mereka berniat untuk memperlihatkan sebuah perilaku. Kepercayaan yang dirasakan oleh masing-masing individu untuk melakukan sebuah perilaku (behavioral belief), diukur berdasarkan hasil dari beberapa evaluasi terhadap konsekuensi yang akan diterima (outcome evaluation) akan menentukan sikap seseorang. Sikap-sikap tersebut diyakini berpengaruh secara langsung terhadap intensi berperilaku yaitu niat. Amalia et al. (2019) menyatakan 
Sri Lilik Puji Rahayu. Peran E-Wom Positif dan Sikap Wisatawan dalam Meningkatkan Niat Berkunjung pada Generasi Millenial (Studi pada Geowisata Selo Bonang Kabupaten Jember)

bahwa sikap wisatawan dapat dikembangkan melalui informasi positif yang dipaparkan oleh wisatawan lain melalui internet yang akhirnya akan meningkatkan niat wisatawan untuk berwisata.

Selain sikap, niat berkunjung juga dipengaruhi oleh aktivitas pemasaran dari pihak pengelola destinasi wisata dan informasi yang diperoleh dari orang lain secara lisan maupun tulisan di media elektronik (Hidayah, 2019:56). Hal ini menjelaskan bahwa e-WOM merupakan salah satu faktor yang dapat memengaruhi seseorang untuk berkunjung ke sebuah destinasi wisata. $e$-WOM merupakan salah satu jenis informasi yang penting bagi wisatawan yang tertarik untuk bepergian ke sebuah destinasi wisata (Amalia et al., 2019; Jalilvand et al., 2012). Lebih lanjut, Zarrad \& Debabi (2015) menyatakan bahwa calon wisatawan cenderung mencari informasi dari eksternal seperti $e$-WOM dan blog untuk menemukan tujuan wisata yang ingin dikunjungi. Gretzel \& Yoo, (2008) dan Jalilvand \& Samiei (2012) mengemukakan bahwa ulasan positif/e-WOM positif dari wisatawan lain sering dianggap sebagai acuan yang dapat diandalkan oleh calon wisatawan.

Saat ini pembangunan pariwisata di Indonesia telah dikembangkan oleh kementrian pariwisata melalui Dinas Pariwisata dengan melakukan berbagai macam aktivitas pemasaran wisata dan perluasan informasi yang termuat dalam RENSTRA Dinas Kebudayaan dan Pariwisata dari masingmasing daerah, salah satunya adalah Kabupaten Jember Jawa Timur yang menjadi obyek utama pengembangan destinasi pariwisata (Pariwisata, 2019). Jember merupakan salah satu kabupaten/kota di provinsi Jawa Timur yang dinobatkan menjadi kota dengan keragaman budaya bertaraf nasional dan internasional melalui Jember Fashion Carnaval dan tergabung dalam salah satu kategori Top 100 Wonderful event (Nasional.tempo.co, 2017). Selain terkenal dengan keragaman budaya Kabupaten Jember juga terkenal dengan Pariwisata yang memiliki keindahan alam salah satunya adalah wisata alam batuan purba yang memiliki keunikan khas yaitu dapat berbunyi seperti alat musik gamelan. Geowisata Selo Bonang terletak di kawasan hutan di kaki pegunungan Argopuro tepatnya di Dusun Sumbercandik Kabupaten Jember Jawa Timur yang dikenal publik pada tahun 2017 karena bantuan internet dan sosial media terutama instagram dan pada tahun 2018 Geowisata Selo Bonang berada dalam proses pengembangan yang dilakukan oleh Dinas Kebudayaan dan Pariwisata provinsi Jawa Timur sebagai destinasi wisata berbasis pada sejarah geologi, namun pada tahun 2019 pengelola wisata menyatakan bahwa Geowisata Selo Bonang mengalami penurunan jumlah pengunjung (Infopol.co.id 2020). Penelitian ini bertujuan untuk mengetahui pengaruh antara variabel $e$-WOM positif terhadap sikap wisatawan, pengaruh antara variabel sikap wisatawan terhadap niat berkunjung suatu destinasi wisata, dan pengaruh antara variabel $e$-WOM positif terhadap niat berkunjung suatu destinasi wisata.

\section{KAJIAN PUSTAKA DAN PENGEMBANGAN HIPOTESIS}

\section{WOM dan $e$-WOM Positif}

Menurut Hasan (2010:32), word of mouth merupakan proses pembagian informasi non komersial baik berupa produk maupun jasa kepada konsumen lain yang dilakukan secara langsung seorang individu. Dalam era digitalisasi saat ini WOM telah dikembangkan menjadi $e$-WOM. WOM disampaikan secara langsung oleh satu pihak ke pihak lain tanpa menggunakan perantara apapun. Sedangkan penyampaian $e$-WOM melalui sebuah media perantara yaitu melalui media elektronik. Menurut Hennig-thurau, Eifler, Hennig-thurau, Gwinner, \& Gremler (2004), komunikasi e-WOM mengacu pada pernyataan positif atau negatif yang dibuat oleh individu sehubungan dengan produk ataupun layanan yang ditulis dan diposting di internet untuk individu dan institusi. Menurut Kotler \& Keller (2016: 645), salah satu bentuk electronic word of mouth (e-WOM) adalah media sosial dan merupakan alat pemasaran yang sangat kuat serta menjadi salah satu faktor pendorong penjualan yang paling efektif. e-WOM telah dikategorikan sebagai positive e-WOM dan negative e-WOM.

$e$-WOM positif merujuk pada pernyataan dan pendapat positif yang diposting melalui internet mapun media sosial dari masing-masing individu yang didasarkan pada pengalaman mereka terhadap sebuah jasa maupun produk. Sedangkan $e$-WOM negatif merujuk pada pernyataan dan pendapat negatif yang diposting melalui internet maupun media sosial dari masing-masing individu yang didasarkan pada pengalaman mereka terhadap sebuah jasa maupun produk (Jalilvand et al., 2012). Dalam mengukur e- 
WOM positif beberapa indikator yang digunakan merupakan kumpulan indikator dari beberapa penelitian yakni berdasarkan penelitian Doosti, Jalilvand, Asadi, Khazaei Pool, \& Adl (2016) dan Humaira \& Wibowo (2016) yang telah disesuaikan dengan objek penelitian yaitu meliputi sering membaca ulasan perjalanan wisatawan lain, tie strengh (ikatan yang kuat), trust (percaya) dan informational influence (pengaruh informasi).

\section{Sikap Wisatawan}

Menurut Schiffman \& Kanuk (2008:222), sikap merupakan suatu kecenderungan yang dipelajari dalam berperilaku dan menilainya dengan cara yang menyenangkan atau tidak menyenangkan terhadap sebuah obyek tertentu. Menurut Theory of Planned Behavior (TPB) yang temukan oleh Ajzen, Icek dan Fishbein (2005), anteseden pertama dari tujuan berperilaku adalah sikap. Sikap merupakan sebuah kepercayaan positif atau negatif yang dapat menjadi salah satu faktor untuk menampilkan suatu perilaku tertentu. Menurut Winarta, Rahayu, \& Kusumawardhany (2016), sikap wisatawan merupakan bagaimana calon wisatawan menilai dan sejauh mana seseorang memiliki penilaian yang menguntungkan (positif) atau tidak menguntungkan (negatif) dari tempat wisata. Dalam mengukur sikap wisatawan beberapa indikator yang digunakan merupakan kumpulan indikator dari beberapa penelitian yakni berdasarkan penelitian Jalilvand et al., (2012), Winarta et al., (2016) dan Suhud, (2016) yang telah disesuaikan dengan objek penelitian yaitu meliputi very bad/very good (sangat buruk/sangat bagus), very worthless/very valuable (sangat tidak berharga/sangat berharga), very unpleasant/very pleasant (sangat tidak menyenangkan/ sangat menyenangkan), uninteresting/interesting (tidak menarik/ menarik)dan desirable /undesirable (diinginkan/tidak diinginkan).

\section{Niat Berkunjung}

Menurut Cahyanti \& Anjaningrum (2018), rasa ketertarikan (interest) yang alami oleh seseorang terhadap sebuah hal dapat ditafsirkan sebagai niat. Terlebih lagi dalam bidang pemasaran pariwisata, definisi niat dapat fokuskan menjadi sebuah ketertarikan yang timbul dalam diri calon wisatawan terhadap sebuah destinasi wisata tertentu. Chen et al., (2014) mendefinisikan niat berkunjung sebagai keinginan dari masing-masing individu untuk berwisata/ mengunjungi suatu destinasi wisata. Niat untuk berkunjung ke suatu tempat tersebut ditafsirkan sebagai kumpulan keseluruhan perhitungan antara biaya dan manfaat yang diperoleh dari beberapa alternatif pilihan tempat wisata yang tersedia, yang mana pilihan tersebut diperoleh dari informasi eksternal termasuk didalamnya $e$-WOM atau blog Zarrad \& Debabi, (2015). Dalam penelitian Amalia et al. (2019), niat berkunjung dianggap sebagai salah satu faktor yang dapat memproses motivasi seseorang yang nantinya akan memengaruhi perilaku serta merupakan sebuah petunjuk seberapa kuatnya keinginan calon wisatawan untuk meninjau dan seberapa banyaknya upaya-upaya yang dilakukan mereka untuk terlibat dalam perilaku. Dalam mengukur niat berkunjung beberapa indikator yang digunakan merupakan kumpulan indikator dari beberapa penelitian, yakni berdasarkan penelitian Quintal \& Phau (2015), Doosti et al., (2016), dan Krishnapillai \& Ying, (2017) yang telah disesuaikan dengan objek penelitian yaitu meliputi berencana untuk mengunjungi, tertarik untuk berkunjung, dan mengeluarkan upaya untuk berkunjung.

\section{Hubungan antar Variabel}

Maraknya penggunaan internet menjadikan e-WOM menjadi salah satu faktor penting yang mampu memengaruhi keinginan seseorang untuk berwisata dan menentukan destinasi mana yang akan dipilih untuk dikunjungi Yun \& Good (2007). Amalia et al. (2019) menyatakan bahwa semakin banyak wisatawan yang menulis pengalaman positif di media sosial $(e-W O M)$ saat mereka berada di sebuah destinasi wisata, maka semakin baik sikap dan niat wisatawan untuk mengunjungi destinasi tersebut. Fakharyan (2012) menyatakan bahwa e-WOM dapat memengaruhi sikap wisatawan dalam proses pengambilan keputusan untuk mengunjungi sebuah destinasi wisata.

H1: e-WOM positif berpengaruh positif dan signifikan terhadap sikap wisatawan.

$\mathrm{H} 2$ : e-WOM positif berpengaruh positif dan signifikan terhadap niat berkunjung. 
Sri Lilik Puji Rahayu. Peran E-Wom Positif dan Sikap Wisatawan dalam Meningkatkan Niat Berkunjung pada Generasi Millenial (Studi pada Geowisata Selo Bonang Kabupaten Jember)

Menurut Amalia et al., (2019), sikap tafsirkan memiliki peran utama dalam perilaku konsumen wisatawan, dibentuk berdasarkan pengalaman sebelumnya yakni merujuk pada kecenderungan untuk menyukai atau tidak menyukai rangsangan tertentu seperti respon terhadap sebuah obyek wisata. Cam et al., (2019) menyatakan bahwa sekali seseorang memiliki sikap positif terhadap sebuah tujuan wisata, kemungkinan tempat wisata tersebut akan dipilih sebagai tempat untuk berlibur. Na, Onn, \& Meng (2016) menyatakan bahwa sikap dapat menjadi anteseden bagi niat wisatawan untuk bepergian ke suatu tempat. Hubungan antar variabel juga dapat dilihat di Gambar 1.

H3: sikap wisatawan berpengaruh positif dan signifikan terhadap niat berkunjung.

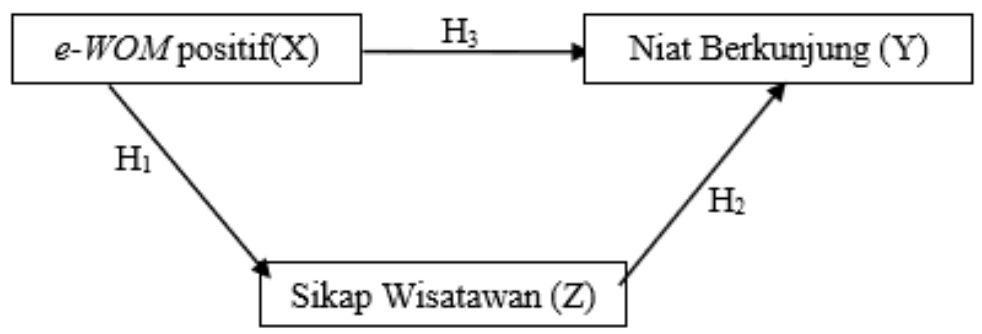

Gambar 1. KERANGKA KONSEPTUAL

\section{METODE PENELITIAN}

Jenis penelitian kuantitatif dipilih dalam penelitian ini. Populasi dalam penelitian ini bersifat infinite yang berarti jumlah populasi yang diteliti tidak diketahui jumlahnya. Karakteristik dalam penelitian adalah seseorang yang berusia 19-41 tahun (generasi millenial), yang merupakan followers akun instagram Geowisata Selo Bonang yang belum pernah berkunjung ke Geowisata Selo Bonang. teknik nonprobability sampling, menggunakan judgmental sampling diterapkan untuk mengambil sampel yang sesuai dengan karakteristik dalam penelitian ini. Responden dalam penelitian ini sejumlah 220 responden. Skala likert dipilih sebagai pengukuran dalam penelitian ini. Penyebaran angket/kuesioner dalam penelitian ini dilakukan secara online dengan menggunakan googleform. Dalam penelitian ini menggunakan teknik analisis data berupa program IBM SPSS AMOS versi 24 dan IBM SPSS versi 23.

\section{HASIL DAN PEMBAHASAN}

\section{Karakteristik Responden}

Karakteristik responden dalam penelitian merupakan keseluruhan profil dari 220 responden yang telah terlibat dalam pengisian kuesioner online penelitian ini. Keseluruhan profil responden yang dipaparkan adalah usia, pekerjaan dan jenis kelamin. Dalam penelitian ini, generasi millenial dengan usia 19-26 tahun lebih mendominasi yaitu berjumlah 142 responden atau setara dengan $(64,5 \%)$. Jika ditinjau dari jenis pekerjaan, sebagian besar responden berstatus sebagai pelajar/mahasiswa yang berjumlah 144 responden atau setara dengan (65,5\%). Jika ditinjau dari jenis kelamin, dalam penelitian ini didominasi oleh laki-laki yang berjumlah 123 responden atau setara dengan $(55,9 \%)$.

\section{Uji Validitas dan Reliabilitas}

Uji validitas dalam penelitian ini dipergunakan untuk mengetahui kevalidan dari masing-masing item pernyataan. Berdasarkan hasil olah data dapat dibuktikan bahwa seluruh item pernyataan variabel $e$ WOM positif, sikap wisatawan, dan niat berkunjung menghasilkan $\mathrm{r}$ hitung $>0,361$, sehingga dapat dinyatakan valid dan seluruh item variabel $e-W O M$ positif, sikap wisatawan, dan niat berkunjung dapat lanjutkan sebagai alat ukur dalam penelitian ini.

Uji reliabilitas dalam penelitian ini dipergunakan untuk mengetahui seberapa reliabilitasnya masingmasing pernyataan. Berdasarkan hasil olah data dapat dibuktikan bahwa seluruh item pernyataan dari masing-masing variabel memiliki nilai Cronbach's Alpha bernilai lebih besar dari 0,70, sehingga 
dapat diketahui bahwa pernyataan yang dibuat dalam instrumen penelitian ini adalah reliable dan dapat dilanjutkan sebagai alat ukur.

\section{Uji Kelayakan Model}

Berlandaskan hasil uji kelayakan model dalam penelitian ini, dapat diketahui bahwa nilai koefisien determinasi $\left(\mathrm{R}^{2}\right) e$-WOM positif terhadap sikap wisatawan $\left(\mathrm{R}^{2} 1\right)$ adalah 0,370 dan nilai koefisien determinasi $e-W O M$ positif terhadap niat berkunjung $\left(\mathrm{R}^{2} 2\right)$ adalah 0,525 . Berdasarkan hasil dari perhitungan ketepatan model menggunakan rumus penelitian diukur dari hubungan koefisien determinasi $\left(\mathrm{R}^{2}\right)$ di kedua persamaan, maka perhitungan tersebut menghasilkan nilai sebesar $70 \%$. Hal tersebut mempresentasikan bahwa kontribusi model untuk memaparkan hubungan sruktural dari ketiga variabel yang diteliti dalam penelitian ini adalah sebesar $0,700(70 \%)$ dan dari sisa hasil tersebut dipaparkan oleh variabel lain yang tidak terkait ke dalam model penelitian.

\section{Uji Analisis Jalur}

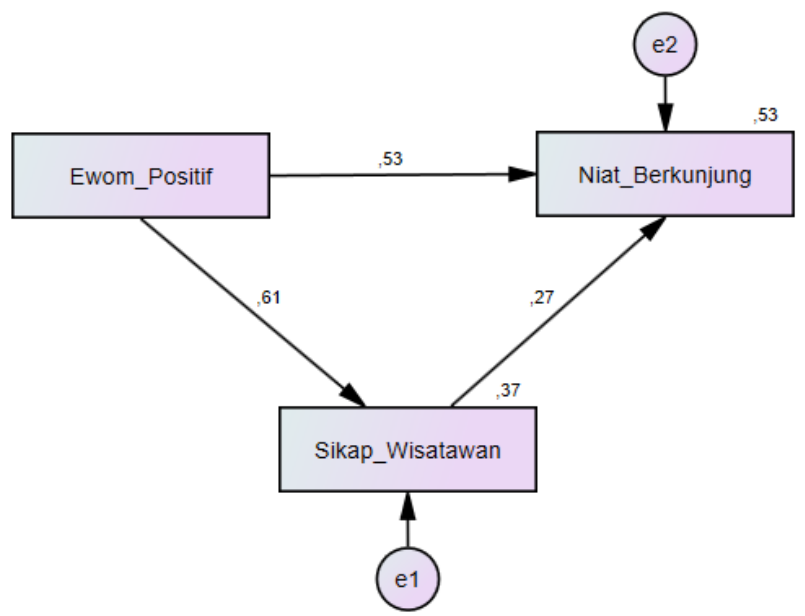

Sumber: Amos versi 24

Gambar 2. HASIL UJI ANALISIS JALUR

Berdasarkan gambar 2. Model analisis jalur di atas memenuhi syarat dan dapat dimasukkan ke sebuah persamaan model struktural. Menurut Sarwono, (2012:38) untuk menghitung nilai dari e1 dan e2 digunakan rumus e $=\sqrt{ } 1-\mathrm{r} 2$. Maka, berikut ini merupakan persamaan model struktural (1) dan (2) dari hasil uji analisis jalur .

$Z=b_{1} X+e 1 \rightarrow Z=0,61+0,793$

$Y=b_{2} Z+b_{3} X+e 2 \rightarrow Y=0,27 Z+0,53 X+0,689$

Tabel 1

STANDARDIZED REGRESSION WEIGHTS

\begin{tabular}{llcc}
\hline & & & Estimate \\
\hline Sikap_Wisatawan & $\leftarrow$ & $e$-WOM_Positif &, 608 \\
Niat_Berkunjung & $\leftarrow$ & Sikap_Wisatawan &, 273 \\
Niat_Berkunjung & $\leftarrow$ & $e$-WOM_Positif &, 526 \\
\hline
\end{tabular}

Sumber: Output AMOS versi 24

Berdasarkan tabel 1, terdapat pengaruh positif antara variabel $e$-WOM positif terhadap variabel sikap wisatawan dengan nilai koefisien jalur sebesar 0,608. Berdasarkan hasil dari nilai tersebut dapat diambil dikatakan bahwa semakin tinggi frekuensi e-WOM positif tentang Geowisata Selo Bonang di media sosial instagram, maka sikap wisatawan terhadap Geowisata Selo Bonang juga semakin baik. Terdapat pengaruh positif antara variabel sikap wisatawan terhadap variabel niat berkunjung dengan 
Sri Lilik Puji Rahayu. Peran E-Wom Positif dan Sikap Wisatawan dalam Meningkatkan Niat Berkunjung pada Generasi Millenial (Studi pada Geowisata Selo Bonang Kabupaten Jember)

nilai koefisien sebesar 0,273 . Berdasarkan hasil dari nilai tersebut dapat dikatakan bahwa semakin baik dan positif sikap wisatawan terhadap Geowisata Selo Bonang maka niat seseorang untuk berkunjung ke Geowisata Selo Bonang juga semakin tinggi. Dan terdapat pengaruh positif antara variabel $e$-WOM positif terhadap variabel niat berkunjung dengan nilai koefisien jalur sebesar 0,526. Berdasarkan hasil dari nilai tersebut dapat dikatakan bahwa semakin tinggi frekuensi $e$-WOM positif di media sosial instagram tentang Geowisata Selo Bonang maka niat seseorang untuk mengunjungi Geowisata Selo Bonang juga semakin tinggi. Berdasarkan pedoman koefisien korelasi menurut (Sarwono, 2012 :59) kemudian untuk mengetahui jenis kategori korelasi terhadap sikap wisatawan dan niat berkunjung dapat dijelaskan sebagai berikut:

Besarnya perubahan variabel sikap wisatawan dan variabel $e$-WOM positif yakni senilai 0,370 . Dari nilai tersebut, maka dapat diketahui bahwa terdapat korelasi cukup antara variabel $e$-WOM positif terhadap variabel sikap wisatawan. Besarnya perubahan variabel niat berkunjung dan variabel $e-W O M$ positif dan sikap wisatawan yakni senilai 0,525 . Berdasarkan nilai tersebut, maka dapat diketahui bahwa terdapat korelasi kuat antara variabel $e$-WOM positif, sikap wisatawan terhadap niat berkunjung.

\section{Uji Hipotesis}

Tabel 2

\section{HASIL UJI HIPOTESIS}

\begin{tabular}{cccccc}
\hline Hipotesis & Variabel & Estimate & S.E. & C.R. & P \\
\hline H1. & Sikap_Wisatawan $\leftarrow e-W O M$ Positif & 0,271 & 0,024 & 11,331 & $0,000$. \\
\hline H2. & Niat_Berkunjung $\leftarrow$ Sikap_Wisatawan & 0,340 & 0,038 & 8,965 & $0,000$. \\
\hline H3. & Niat_Berkunjung $\leftarrow e-W O M$ Positif & 0,395 & 0,085 & 4,647 & $0,000$. \\
\hline
\end{tabular}

Sumber: Output AMOS versi 24

Pada tabel 2, variabel $e$-WOM positif terhadap variabel sikap wisatawan menghasilkan CR hitung dengan nilai $11,331>2,00$ dan untuk hasil probabilitas signifikansinya diketahui senilai $0,000(\mathrm{p} \leq$ $0,05)$. Hasil ini membuktikan bahwa variabel $e$-WOM positif mempunyai pengaruh signifikan terhadap variabel sikap wisatawan dan dapat artikan bahwa hipotesis dapat diterima. Selanjutnya, antara variabel sikap wisatawan terhadap variabel niat berkunjung menghasilkan CR hitung dengan nilai 8,965 > 2,00 dan untuk hasil probabilitas signifikansinya diketahui senilai $0,000(\mathrm{p} \leq 0,05)$. Hasil ini membuktikan bahwa variabel sikap wisatawan mempunyai pengaruh signifikan terhadap variabel niat berkunjung dan dapat diartikan bahwa hipotesis dapat diterima. Dan variabel $e$-WOM positif terhadap variabel niat berkunjung menghasilkan CR hitung dengan nilai 4,647 > 2,00 dan untuk hasil probabilitas signifikansinya diketahui senilai $0,000(\mathrm{p} \leq 0,05)$. Hasil ini membuktikan bahwa variabel $e$-WOM positif mempunyai pengaruh signifikan terhadap variabel niat berkunjung dan dapat artikan bahwa hipotesis dapat diterima.

\section{Uji Mediasi}

Mediasi secara parsial menjadi hasil akhir dari uji mediasi dalam penelitian ini. Hasil ini diperoleh karena variabel $e-W O M$ positif terhadap variabel niat berkunjung signifikan dan menurun tidak sama dengan 0 dengan memasukkan variabel sikap wisatawan. Variabel X ( $e$-WOM positif) berpengaruh terhadap variabel Y (niat berkunjung) namun, pengaruhnya akan lebih besar jika melalui variabel Z (sikap wisatawan). Jadi semakin banyaknya e-WOM positif akan memengaruhi sikap seseorang dan semakin baiknya sikap seseorang, maka niat berkunjungnya pun akan semakin tinggi.

\section{Pengaruh $e$-WOM Positif terhadap Sikap Wisatawan}

$e$-WOM merupakan informasi yang diberikan konsumen terhadap orang lain melalui media elektronik. Saat ini seringkali para generasi milenial menyampaikan ulasan tentang tempat wisata yang pernah dikunjunginya di sosial media, terutama instagram. Ulasan tersebut merupakan sumber informasi bagi seseorang terhadap suatu tempat wisata. Jika ulasan yang disampaikan menarik dan memberikan informasi yang bersifat positif maka akan memberikan rasa senang bagi seseorang sehingga menimbulkan sikap positif pada tempat wisata tersebut. Hasil akhir dalam penelitian ini menunjukkan 
bahwa variabel $e-W O M$ positif berpengaruh positif dan signifikan terhadap variabel sikap wisatawan yang turut mendukung beberapa penelitian terdahulu (Doosti et al., 2016; Jalilvand \& Samiei, 2012) telah menunjukkan hasil bahwa $e$-WOM positif dapat memengaruhi sikap wistawan, Pietro, Virgilio, \& Pantano (2010) juga menemukan hasil penelitian bahwa $e$-WOM memiliki efek positif yang signifikan terhadap sikap terhadap tujuan yang didukung oleh jejaring sosial, yang dapat dijadikan sebagai alat berbagi pengalaman dan menambah pengetahuan baru. Namun, hasil penelitian ini tidak mendukung hasil penelitian yang dilakukan oleh Chaerunnisaa \& Setyowardhani, (2013) serta Wijaya \& Alversia, (2012) yang menyatakan bahwa e-WOM positif tidak berpengaruh signifikan terhadap sikap wisatawan.

Hasil dalam penelitian ini juga selaras dengan teori dari Schiffman \& Kanuk (2008:222) yang menyatakan bahwa sikap merupakan kecenderungan yang dipelajari, artinya sikap yang berkaitan dengan perilaku pembelian dibangun sebagai hasil dari pengalaman yang berkaitan langsung dengan produk, informasi yang diperoleh melalui orang lain baik melalui lisan maupun terpapar dalam media elektronik dan internet $(e-W O M)$. $e$-WOM diakui memainkan peran penting untuk memengaruhi dan membangun sikap wisatawan dan niat berperilaku seseorang Jalilvand et al., (2012). Sebuah komunikasi $e-W O M$ akan sangat memengaruhi calon wisatawan yang tertarik dengan ulasan wisatawan lain yang lebih berpengalaman dengan sebuah destinasi wisata. Faktanya masing-masing individu akan lebih percaya pendapat orang lain yang lebih berpengalaman dengan destinasi tersebut daripada promosi-promosi yang dilakukan oleh pihak pengelola destinasi wisata, di mana rasa percaya yang dirasakan akan memunculkan sebuah sikap dari calon wisatawan tersebut Cam, Anh, Moslehpour, \& Thanh, (2019); Winarta et al., (2016). Berdasarkan beberapa teori di atas terbukti pada kenyataannya dalam beberapa postingan pada akun instagram Geowisata Selo Bonang menunjukkan beragam respon positif yang diberikan calon wisatawan terhadap keindahan alam dan berbagai kegiatan unik yang dapat dilakukan saat berwisata seperti bemain batu gamelan, berkebun, maupun tracking. Hal ini juga di dukung dengan hasil angket pada penelitian ini yang menunjukkan bahwa di mana sebagian besar informasi yang dicari oleh calon wisatawan adalah komentar/ulasan positif tentang keindahan dari pemandangan Geowisata Selo Bonang melalui media sosial instagram.

Indikator yang digunakan untuk mengukur variabel $e$-WOM positif dalam penelitian ini yaitu : membaca ulasan perjalanan wisatawan lain, tie strengh, trust, dan informational influence. Tingkat respon tertinggi terdapat pada indikator informational influence dengan item pernyataan "saya mendapatkan informasi tentang pemandangan Geowisata Selo Bonang melalui instagram" yang dapat diartikan bahwa sebelum memilih Geowisata Selo Bonang sebagai tujuan wisata, calon wisatawan akan mencari ulasan positif/e-WOM positif dari pengalaman wisatawan lain yang pernah berkunjung pada postingan akun Geowisata Selo Bonang. informasi berupa keindahan alam yang dirasakan saat berkunjung ke Geowisata Selo Bonang akan terekam dan teringat dalam pikiran calon wisatawan yang nantinya akan memunculkan sikap positif dari calon wisatawan terhadap Geowisata Selo Bonang.

\section{Pengaruh Sikap Wisatawan terhadap Niat Berkunjung}

Sikap menggambarkan penilaian seseorang terhadap sebuah obyek tertentu, di mana penilaian tersebut mencakup "bagus/jeleknya" sebuah obyek. Semakin positif sikap seseorang maka akan memperkuat niat mereka untuk melakukan perilaku tertentu. Dalam penelitian ini, perilaku tertentu yang dimaksud adalah niat untuk berkunjung ke sebuah destinasi wisata. Hasil akhir dalam penelitian ini menunjukkan bahwa variabel sikap wisatawan berpengaruh positif dan signifikan terhadap variabel niat berkunjung yang turut mendukung beberapa penelitian terdahulu (Doosti et al., 2016; Jalilvand \& Samiei, 2012; Liu, Li, Yen, \& Sher, 2018; Jalilvand et al., 2012; Rizky, Kusdi, \& Yusri, 2017) yang menunjukkan bahwa sikap wisatawan berpengaruh positif dan signifikan terhadap variabel niat berkunjung, Na et al., (2016) menyatakan bahwa sikap positif dapat menjadi anteseden bagi niat wisatawan untuk bepergian ke suatu tempat. Namun, hasil penelitian ini tidak mendukung hasil penelitian yang dilakukan oleh Winarta et al., (2016) yang menyatakan bahwa sikap wisatawan tidak berpengaruh signifikan terhadap niat berkunjung. 
Hasil dalam penelitian ini juga selaras dengan teori yang dikemukakan oleh Ajzen, Icek dan Fishbein, (2005) bahwa anteseden pertama dari tujuan berperilaku adalah sikap. Schiffman \& Kanuk (2008:222) menyatakan bahwa $\mathrm{n}$ iat berkaitan erat dengan sikap. Niat berkunjung bergantaung pada baik/buruknya sikap wisatawan terhadap obyek wisata, di mana semakin positif sikap wisatawan terhadap destinasi wisata maka akan semakin kuat pula keinginan/niat individu untuk mengunjungi sebuah destinasi wisata tersebut. Secara sederhananya, dapat dikatakan bahwa sekali seseorang memiliki sikap positif terhadap satu tujuan, tujuan tersebut kemungkinan akan dipilih untuk liburannya untuk liburan Cam et al., (2019). Berdasarkan beberapa teori di atas terbukti pada kenyataannya dalam setiap postingan foto/video unggahan akun instagram Geowisata Selo Bonang selalu mendapatkan respon/sikap positif dari calon wisatawan seperti "tempat ini bagus dan sangat rekomendasi untuk dikunjungi". Hal ini juga didukung dengan hasil angket pada penelitian ini yang menunjukkan bahwa di mana sebagian besar responden memberikan sikap yang baik dan menganggap Geowisata Selo Bonang merupakan tujuan wisata yang bagus untuk dikunjungi.

Indikator yang digunakan untuk mengukur variabel sikap wisatawan dalam penelitian ini yaitu :Very bad/Very good (Sangat buruk/sangat bagus),Very worthless/Very valuable (Sangat tidak berharga/sangat berharga), Very unpleasant/Very pleasant (Sangat tidak menyenangkan/ sangat menyenangkan), Uninteresting/interesting (tidak menarik/ menarik) dan Desirable /undesirable (diinginkan/tidak diinginkan). Ti ngkat respon tertinggi terdapat pada item pernyataan "Geowisata Selo Bonang sangat bagus untuk dijadikan sebagai tujuan wisata" yang dapat diartikan bahwa Penilaian calon wisatawan terhadap sebuah destinasi wisata akan memengaruhi tindakan untuk melakukan sebuah perilaku tertentu, jika penilaian tersebut berubah menjadi hal yang menyenangkan dan menimbulkan perasaan senang atau positif akan cenderung membentuk sebuah sikap positif pada diri calon wisatawan terhadap Geowisata Selo Bonang yang nantinya akan meningkatkan niat berkunjung ke Geowisata Selo Bonang.

\section{Pengaruh $\boldsymbol{e}$-WOM Positif terhadap Niat Berkunjung ke Geowisata Selo Bonang}

Perkembangan internet memudahkan calon wisatawan untuk memperoleh informasi mengenai hal-hal tertentu, salah satunya adalah informasi tentang travelling. Komentar/ulasan positif yang diberikan oleh orang lain di media sosial instagram akan menimbulkan rasa ketertarikan calon wisatawan untuk mencari lebih banyak informasi yang dibutuhkan untuk berwisata. Semakin banyak ulasan positif/eWOM positif yang diberikan orang lain, akan memengaruhi niat seseorang untuk berkunjung ke sebuah destinasi wisata. Hasil akhir dalam penelitian ini menunjukkan bahwa variabel $e$-WOM positif berpengaruh positif dan signifikan terhadap variabel niat berkunjung. Yang turut mendukung beberapa penelitian terdahulu (Cam et al., 2019; Doosti et al., 2016; Jalilvand et al., 2012; Winarta et al., 2016) yang menunjukkan bahwa $e$-WOM positif berpengaruh terhadap niat berkunjung. Namun, hasil penelitian ini tidak mendukung hasil penelitian yang dilakukan oleh Jalilvand \& Samiei, (2012) yang menyatakan bahwa $e$-WOM positif tidak berpengaruh terhadap niat berkunjung.

Hasil dalam penelitian ini juga selaras dengan teori penelitian Yun \& Good (2007) yang mengemukakan bahwa terdapat faktor penting yang mampu memengaruhi keinginan seseorang untuk berwisata dan menentukan destinasi mana yang dipilih dan akan dikunjungi, faktor tersebut adalah $e$ WOM. Niat berkunjung mengacu pada wisatawan yang memberikan respon/komentar tentang sebuah destinasi wisata untuk calon wisatawan melalui media sosial instagram, hal tersebut menyebabkan $e$ WOM dapat menjadi sebuah rekomendasi yang akan memengaruhi niat wisatawan untuk berkunjung. Dalam era digital saat ini informasi $e$-WOM menjadi faktor penting yang berpengaruh bagi wisatawan untuk memilih tujuan wisata Amalia et al., (2019). Zarrad \& Debabi, (2015) menunjukkan bahwa informasi eksternal seperti $e-W O M$ dan blog dapat mempermudah proses pencarian tempat wisata yang ingin dikunjungi. Gretzel \& Yoo (2008) mengemukakan bahwa ulasan positif/e-WOM positif dari wisatawan lain sering dianggap sebagai acuan yang dapat diandalkan. Dalam beberapa penelitian $e$-WOM diakui memiliki peran penting dalam memengaruhi dan membangun sikap wisatawan dan niat berperilaku mereka Jalilvand et al., (2012). Dalam penelitian Amalia et al., (2019) juga menemukan bukti bahwa $e$-WOM positif berpengaruh positif dan signifikan terhadap niat berkunjung dengan dimediasi oleh sikap. Hal ini menyiratkan bahwa banyaknya wisatawan yang menulis pengalaman positif di media sosial instagram $(e-W O M)$ saat mereka berada di sebuah destinasi wisata 
akan memengaruhi niat seseorang untuk berkunjung yang didukung dengan adanya sikap yang baik/menyenangkan terhadap sebuah destinasi wisata melalui informasi yang diperoleh dari media sosial instagram. Fakharyan, (2012) mengemukakan bahwa $e$-WOM berpengaruh terhadap sikap wisatawan yang mana kemudian akan berpengaruh terhadap niat berkunjung sebelum memutuskan untuk berwisata. Berdasarkan beberapa teori di atas terbukti dengan hasil angket pada penelitian ini yang menunjukkan bahwa di mana sebagian besar responden informasi yang dicari oleh calon wisatawan adalah visualisasi dari Geowisata Selo Bonang melalui media sosial instagram.

Indikator yang digunakan untuk mengukur variabel niat berkunjung dalam penelitian ini yaitu: berencana untuk mengunjungi, tertarik untuk berkunjung, dan mengeluarkan upaya untuk berkunjung. Tingkat respon tertinggi terdapat pada indikator mengeluarkan upaya untuk berkunjung dengan item pernyataan "saya akan mencari lebih banyak visualisasi dari Geowisata Selo Bonang melalui instagram" yang dapat diartikan bahwa pencarian informasi baik berupa ulasan ataupun visualisasi dari Geowisata Selo Bonang perlu dilakukan untuk membangun rasa ketertarikan dari calon wisatawan serta memberikan gambaran tentang kondisi Geowisata Selo Bonang terutama untuk generasi millenial. Semakin seseorang memahami sebuah obyek wisata maka akan meningkatkan niat berkunjung ke Geowisata Selo Bonang.

\section{KESIMPULAN}

Berdasarkan hasil dan analisis data, serta hasil dalam penelitian ini, maka kesimpulan dari penelitian ini adalah $e$-WOM positif memiliki pengaruh positif dan signifikan terhadap sikap wisatawan pada Geowisata Selo Bonang, Sikap wisatawan memiliki pengaruh positif dan signifikan terhadap niat berkunjung pada Geowisata Selo Bonang, $e$-WOM positif memiliki pengaruh positif dan signifikan terhadap niat berkunjung pada Geowisata Selo Bonang. Keterbatasan dalam penelitian ini adalah membutuhkan responden dengan kriteria belum pernah mengunjungi Geowisata Selo Bonang. Mungkin cenderung menyulitkan beberapa responden ketika mereka belum memiliki gambaran umum tentang Geowisata Selo Bonang, hanya fokus ke media sosial instagram. Diharapkan untuk penelitian selanjutnya agar memanfaatkan media sosial lainnya. Terdapat variabel-variabel lain yang dapat memengaruhi niat berkunjung ke sebuah destinasi wisata seperti kendala perjalanan (travel construct), aksesbilitas, fasilitas maupun konstruk TPB lainnya. Penelitian selanjutnya dapat melibatkan variabel-variabel tersebut.

\section{DAFTAR PUSTAKA}

Ajzen, Icek dan Fishbein, M. (2005). The Theory of Planned Behavior. Tagliche Praxis, 53(1), 51-58.

Amalia, R., Yahya, A., Nurhalis, N., Idris, S., Mahdi, S., Putra, T. R. I., \& Sartiyah, S. (2019). Impact of Electronic Word of Mouth on Tourist Attitude and Intention to Visit Islamic Destinations. Advances in Social Science, Education and Humanities Research, 92(January), 700-770.

Apjii.or.id. 2018. Hasil Survei Penetrasi dan Perilaku Pengguna Internet Indonesia 2018. (https://apjii.or.id/survei. Diakses pada 10 Oktober 2019).

Ariana, N., \& Sudiarta, I. N. (2006). Impliementasi marketing mix pada masingmasing tahap life cycle pariwisata Bali. Journal Manajemen Pariwisata, 6 (2) . Ar, 85-102.

Cahyanti, M. M., \& Anjaningrum, W. D. (2018). Meningkatkan Niat Berkunjung Pada Generasi Muda Melalui Citra Destinasi Dan Daya Tarik Kampung Wisata. Jurnal Ilmiah Bisnis Dan Ekonomi Asia, 11(2), 35-41.

Cam, L. N. T., Anh, T. T., Moslehpour, M., \& Thanh, X. D. T. (2019). Exploring the impact of traditional and electronic word of mouth on travel intention. ACM International Conference Proceeding Series, 25-28, 83-87. 
Sri Lilik Puji Rahayu. Peran E-Wom Positif dan Sikap Wisatawan dalam Meningkatkan Niat Berkunjung pada Generasi Millenial (Studi pada Geowisata Selo Bonang Kabupaten Jember)

Chaerunnisaa, D., \& Setyowardhani, H. (2013). Analisis Hubungan Electronic Word Of Mouth, Citra Daerah Tujuan Wisata, Sikap Wisatawan Terhadap Daerah Tujuan Wisata, dan Keinginan Berwisata. (Studi Kasus : Daerah Istimewa Yogyakarta).

Chen, Y. C., Shang, R. A., \& Li, M. J. (2014). The effects of perceived relevance of travel blogs' content on the behavioral intention to visit a tourist destination. Computers in Human Behavior, $30,787-799$.

Doosti, S., Jalilvand, M. R., Asadi, A., Khazaei Pool, J., \& Mehrani Adl, P. (2016). Analyzing the influence of electronic word of mouth on visit intention: the mediating role of tourists' attitude and city image. International Journal of Tourism Cities, 2(2), 137-148.

Fakharyan, M. (2012). The influence of online word of mouth communications on tourists' attitudes toward Islamic destinations and travel intention: Evidence from Iran. African Journal of Business Management, 6(33), 10381-10388.

Gretzel, U., \& Yoo, K. H. (2008). Use and Impact of Online Travel Reviews. Information and Communication Technologies in Tourism 2008, 35-46.

Hasan, A. (2010). MarketingDari Mulut ke Mulut Words Of MouthMarketing. Yogyakarta: Media Presindo.

Hennig-thurau, T., Eifler, V., Hennig-thurau, T., Gwinner, K. P., \& Gremler, D. D. (2004). Electronic Word-Of-Mouth Via Consumer-Opinion Platforms: What Motivates Consumers To Articulate Themselves On The Internet? 18(1).

Hidayah, N. (2019). Pemasaran Destinasi Pariwisata (1st ed.; Alfabeta, Ed.). Indonesia: Alfabeta Bandung.

Humaira, A., \& Wibowo, L. A. (2016). Analisis Faktor Elektronik Word Of Mouth (EWOM) Dalam Memengaruhi Keputusan Berkunjung Wisatawan. Tourism and Hospitality Essentials (THE) Journal, VI(2), 1049-1060.

Infopol.co.id. 2020. Selo Bonang, Paduan Sejarah Geologi Peradaban Dan Keindahan Panorama Gunung Api Argopuro Purba. (https://www.infopol.co.id/selo-bonang-paduan-sejarah-geologi. Diakses pada 18 Maret 2020).

Jalilvand, M. R., \& Samiei, N. (2012). The impact of electronic word of mouth on a tourism destination choice: Testing the theory of planned behavior (TPB). Internet Research, 22(5), 591-612.

Krishnapillai, G., \& Ying, K. S. (2017). The Infl uence of Electronic-Word-of-Mouth on Travel Intention among Foreign Students in Malaysia: Does Gender Really Matter? International Review of Management and Marketing, 7(1), 475-483.

Kumparan travel. 2019. tiga produk kemenpar untuk kaum milenial. (https:// kumparan.com/kumparantravel/tiga-produk-kemenpar-untuk-kaum-milenial-apa-saja. Diakses pada 10 Oktober 2019).

Liu, Y.-C., Li, I.-J., Yen, S.-Y., \& Sher, P. J. (2018). What Makes Muslim Friendly Tourism? An Empirical Study on Destination Image, Tourist Attitude and Travel Intention. Advances in Management \& Applied Economics, 8(5), 1792-7552.

Na, S. A., Onn, C. Y., \& Meng, C. L. (2016). Travel Intentions among Foreign Tourists for Medical Treatment in Malaysia: An Empirical Study. Procedia - Social and Behavioral Sciences, 
224(August 2015), 546-553.

Nasional.tempo.co. 2017. Jember dinobatkan jadi kota karnaval internasional. (https://nasional.tempo.co/read/893194/jember-dinobatkan-jadi-kota-karnaval-internasional. Diakses pada 11 Oktober 2019).

Pariwisata, D. (2019). Rencana Strategis Pengembangan Pariwisata Jawa Timur 2018-2024. Jawa Timur.

Philip Kotler, K. L. K. (2016). Marketing Management (15e ed.). England: Pearson Education Limited.

Pietro, L. Di, Virgilio, F. Di, \& Pantano, E. (2010). Social network for the choice of tourist destination: attitude and behavioural intention. Journal of Hospitality and Tourism Technology, $3(1), 1-5$.

Quintal, V., \& Phau, I. (2015). The role of movie images and its impact on destination choice. Tourism Review, 70(2), 97-115.

Reza Jalilvand, M., Samiei, N., Dini, B., \& Yaghoubi Manzari, P. (2012). Examining the structural relationships of electronic word of mouth, destination image, tourist attitude toward destination and travel intention: An integrated approach. Journal of Destination Marketing and Management, 1(1-2), 134-143.

Rizky, R. M., Kusdi, R., \& Yusri, A. (2017). The Impact E-WOM On Destination Image, Attitude Toward Destination And Travel Intention. RJOAS, 1(January), 112-118.

Sarwono, J. (2012). Path Analaysis Untuk Riset Skripsi, Tesis dan Disertasi. Jakarta: Elex Media Kumpotindo.

Schiffman, L., \& Kanuk, L. L. (2008). Perilaku Konsumen. Jakarta: PT. INDEK.

Suhud, U. (2016). A study to examine the role of environmental motivation and sensation seeking personality to predict behavioral intention in volunteer tourism. 4(January 2015), 16-30.

Travel.tempo.com. 2019. Travel Blogger Trinity Membaca Tren Gaya Wisata Generasi Milenial. (https://travel.tempo.co/read/1219372/travel-blogger-trinity-membaca-tren-gaya-wisatagenerasi-milenial. Diakses pada 28 November 2019).

Whang, H., Yong, S., \& Ko, E. (2016). Pop culture, destination images, and visit intentions: Theory and research on travel motivations of Chinese and Russian tourists. Journal of Business Research, 69(2), 631-641.

Wijaya, welly frank, \& Alversia, Y. (2012). Pengaruh Electronic Word Of Mouth Terhadap Citra Daerah Wisata, Sikap Wisatawan, dan Niat Melakukan Perjalanan Wisata Studi Kasus: Pariwisata di Bali dan Phuket. ECo-Buss.

Winarta, V., Rahayu, \& Kusumawardhany, P. A. (2016). EWOM Effect On Intention To Visit Raja Ampat Papua (Theory of Planned Behavior). Journal of Business Research.

Yun, Z. S., \& Good, L. K. (2007). Developing customer loyalty from e-tail store image attributes. Managing Service Quality: An International Journal, 17(1), 4-22.

Zakarija Achmat. (2015). Theory of Planned Behavior Masihkah Relevan. Academiaedu, 1-26. 
Sri Lilik Puji Rahayu. Peran E-Wom Positif dan Sikap Wisatawan dalam Meningkatkan Niat Berkunjung pada Generasi Millenial (Studi pada Geowisata Selo Bonang Kabupaten Jember)

Zarrad, H., \& Debabi, M. (2015). Analyzing the Effect of Electronic Word of Mouth on Tourists' attitude toward Destination and Travel Intention. International Research Journal of Social Sciences, 4(4), 53-60. 